\title{
Plant species- and stage-specific differences in microbial decay of mangrove leaf litter: the older the better?
}

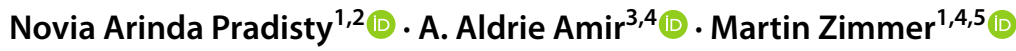

Received: 27 April 2020 / Accepted: 24 November 2020 / Published online: 9 February 2021

(c) The Author(s) 2021, corrected publication 2021

\begin{abstract}
Leaf litter and its breakdown products represent an important input of organic matter and nutrients to mangrove sediments and adjacent coastal ecosystems. It is commonly assumed that old-grown stands with mature trees contribute more to the permanent sediment organic matter pool than younger stands. However, neither are interspecific differences in leaf decay rates taken into account in this assumption nor is our understanding of the underlying mechanisms or drivers of differences in leaf chemistry sufficient. This study examines the influence of different plant species and ontogenetic stage on the microbial decay of mangrove leaf litter. A litterbag experiment was conducted in the Matang Mangrove Forest Reserve, Malaysia, to monitor leaf litter mass loss, and changes in leaf litter chemistry and microbial enzyme activity. Four mangrove species of different morphologies were selected, namely the trees Rhizophora apiculata and Bruguiera parviflora, the fern Acrostichum aureum and the shrub Acanthus ilicifolius. Decay rates of mangrove leaf litter decreased from A. ilicifolius to R. apiculata to B. parviflora to A. aureum. Leaf litter mass, total phenolic content, protein precipitation capacity and phenol oxidase activity were found to decline rapidly during the early stage of decay. Leaf litter from immature plants differed from that of mature plants in total phenolic content, phenolic signature, protein precipitating capacity and protease activity. For R. apiculata, but not of the other species, leaf litter from immature plants decayed faster than the litter of mature plants. The findings of this study advance our understanding of the organic matter dynamics in mangrove stands of different compositions and ages and will, thus, prove useful in mangrove forest management.
\end{abstract}

Keywords Leaf litter $\cdot$ Microbial decay $\cdot$ Leaf chemistry $\cdot$ Extracellular enzyme activity $\cdot$ Mangrove management

Communicated by Stephan Hattenschwiler.

This study disproves the common assumption in blue carbon research that $\mathrm{N}$ content and $\mathrm{C}: \mathrm{N}$ ratio, alone, affect mangrove leaf litter decay. Rather, the results show that tree age and species effects are more important in determining mangrove litter decomposition. This work fills the knowledge gap on potential drivers of leaf litter decay in mangrove ecosystems, which are of high importance to the sequestration of atmospheric carbon dioxide.

Novia Arinda Pradisty

novia.arinda@kkp.go.id

1 Faculty 2 Biology/Chemistry, Universität Bremen, Bremen, Germany

2 Institute for Marine Research and Observation, Ministry of Marine Affairs and Fisheries, Negara, Bali, Indonesia

3 Institute for Environment and Development (LESTARI), Universiti Kebangsaan Malaysia, Bangi, Selangor, Malaysia

4 IUCN SSC Mangrove Specialist Group, London, England

5 Leibniz Centre for Tropical Marine Research, ZMT-GmbH, Bremen, Germany

\section{Introduction}

Mangroves are an ecological assemblage of trees, palms, shrubs and ferns adapted to grow above mean sea level in the upper intertidal region of coastal and estuarine environments in tropical and sub-tropical latitudes (Duke, 2011; Feller et al. 2010). As one of the most productive ecosystems, mangroves store vast amounts of organic matter in their sediment, where anoxic conditions result in a slow turnover of accumulated detritus from various sources (Donato et al. 2011; Murdiyarso et al. 2015). Thus, they contribute significantly to climate change-mitigation through their "blue carbon" stocks. Organic matter in mangrove sediments originates from detritus of both local sources (i.e. mangroves, microphytobenthos) and tidal inputs (e.g. phytoplankton, seagrass and macroalgae), with varying relative inputs of these sources both within and among different mangrove sites (Bouillon et al. 2004). 
Apart from their important role in greenhouse gas sequestration, mangroves also provide various economic and societal benefits for human wellbeing, from securing food and non-food resources to nature-based solutions for coastal protection and recreation (van Oudenhoven et al. 2015). Wood extraction is among the oldest uses of natural resources provided by mangroves. Sustainable silvicultural management, implementing rotation cycles and selective logging practices, that allow for recolonization and regrowth of dense mangrove stands between clear-felling events has been practiced in only a few places, such as the Matang Mangrove Forest Reserve (MMFR) in Peninsular Malaysia, the Bintuni Bay Mangroves in West Papua, Indonesia, and the Sundarbans in Bangladesh (Ariffin and Nik Mohd Shah 2013; Iftekhar and Islam 2004; Sillanpää et al. 2017).

Trying to link these practices that affect mangrove stand age with the dynamics of organic matter-turnover, our understanding of potential drivers of leaf litter decay, such as plant species and age, is still limited. In terrestrial ecosystems, the availability of soil nutrients and turnover rates of organic matter decline as forests age (Gower et al. 1996; Ryan et al. 1997). Like other forest stands, mangroves follow a natural series of phases over time from an initial pioneering stage to rapid early growth and development, to later maturity, senescence and death (Jimenez et al. 1985). The aboveground net primary production (ANPP) reaches a peak early in forest stand development and then gradually declines as stands age (Berger et al. 2004; Gower et al. 1996; Alongi 2002; Alongi and Dixon 2000; Clough et al. 1999).

As a mangrove forest grows older, tree density declines naturally due to self-thinning, allowing for higher individual growth rates, and thus, providing higher aboveground biomass at the stand-scale with increasing age (Clough et al. 1999). In Northern Brazil, the annual leaf litter production steadily increases from early successional Avicennia germinans stands to late succession stages of Rhizophora mangle, while leaf litter quality steadily decreases (Quadros et al. 2019). Mature, old-grown mangrove stands rejuvenate naturally through the death of individual trees (Duke 2001) and lightning strikes (Zhang et al. 2008; Amir 2012), providing space and improved light conditions for dormant seedlings to replace the canopies of the dead trees. While such natural dynamics can be compared to man-made dynamics of forest management, the survival and recovery of mangrove forests are highly related to the scale of damage. In Honduras, mass mangrove tree mortality after severe storms caused rapid sediment elevation loss through the decay of dead root material and sediment compaction (Cahoon et al. 2003). Significant loss of organic $\mathrm{C}$ and $\mathrm{N}$ stocks was observed in a silvicultural mangrove stand of the MMFR, when compared to a reference site without any harvesting activities for more than 70 years (Adame et al. 2018).
A great proportion of the mangrove ANPP is shed as litter (Komiyama et al. 2008; Ong et al. 1995), which the leaf fraction being the largest contributor of total litter fall (Mfilinge et al. 2005; Nga et al. 2005). In general, plant litter decay and decomposition follow three main stages: (1) leaching of soluble components, (2) physical fragmentation and biological breakdown, and (3) microbial degradation of refractory components such as cellulose, hemicellulose, cutin and lignins (Valiela et al. 1985; Opsahl and Benner 1995; Zimmer 2019). Leaching accelerates litter degradation by promoting microbial activity and increasing the palatability of the litter to detritivores (Zimmer 2019). Fast decay and decomposition of detrital material with high $\mathrm{N}$-content (or low C:N ratio) or low content of deterrent or recalcitrant compounds, such as phenolics, lignins or cellulose, have been associated with high rates of nutrientturnover, rendering nutrients available for uptake by plants (and microbes) soon after litter fall. On the contrary, slowly decaying litter provides a longer-lasting pool of nutrients to be released into the soil or sediment environment more evenly over time. Upon burial into the belowground pool (for review, see Krishna and Mohan 2017), organic matter becomes more recalcitrant and degrades only slowly under saline and anoxic conditions (Kida et al. 2019). Further stabilization of organic matter is also induced by aggregation and strong chemical bonding to the mineral soil matrix (Cotrufo et al. 2013). Microbes influence the formation of organic matter through the transformation of plant residues by extracellular enzyme attacks and utilization of organic substrates via cell uptake. Insoluble structural carbohydrates and other complex biopolymers are subject to attack by microbial extracellular enzymes (Zimmer, 2019). Microbes convert the detrital organic matter into their own biomass, a process called immobilization, resulting in increasing amino acid and protein, as well as fatty acid and lipid contents of the detritus along with the decay processes (Mfilinge et al. 2003; Tremblay and Benner, 2006). Microbial immobilization generates compounds that are more stable or resistant against further degradation (Liang et al. 2017).

Much effort has been made to identify plant traits that drive decay and decomposition rates, an understanding of which is essential for accurate forecasts of the future carbon cycle. Cornwell et al. (2008) assigned leaf traits of different phylogenetic groups (e.g. N, P, lignins, leaf mass per area, water and acid soluble polysaccharides) to decomposition rates. In a study in India, the $\mathrm{N}$ content of yellow leaves was similar in the mangrove species Rhizophora mucronata, $R$. apiculata, Sonneratia alba and Avicennia officinalis, but the decomposition rate of $A$. officinalis was much higher than of the other three species (Wafar et al. 1997). In Malaysia, the litter of S. alba decomposed much faster than that of Rhizophora spp. and Bruguiera parviflora (Ashton et al. 1999). Kandelia candel litter decomposed faster than Bruguiera 
gymnorhiza litter in Japan, despite having a higher total phenolic content (Mfilinge et al. 2002); their senescent leaves differed markedly in initial $\mathrm{N}$ and $\mathrm{P}$ content, and $\mathrm{C}: \mathrm{N}$ ratio. In Hong Kong, however, differences in decomposition rates between Avicennia corniculatum and $K$. candel were not explained by initial C:N ratios (Tam et al. 1990). The leaf litter of mangrove associates degrades at a higher rate than that of true mangroves (Chanda et al. 2016).

The content of phenolic compounds, specifically tannins, which are widely distributed among higher plants, is suggested to be a good predictor of decay, decomposition, nitrogen immobilization and mineralization (Maie et al. 2008). Rather than the phenolic content, however, the specific signature (fingerprint) of phenolic compounds can explain their biological activity (Zimmer et al. 2015). Tannins form recalcitrant complexes with proteins and thus impair decay processes through microbial extracellular enzymes (Kraus et al. 2003a). Members of the mangrove families Acanthaceae, Rhizophoraceae, and Sonneratiaceae are rich in tannins (Bandaranayake 1995), but tannin fate during decay in mangroves remains poorly understood (Constabel et al. 2014).

In particular, field studies on mangrove leaf litter decay and corresponding changes in leaf chemistry are still limited, even more so with respect to litter from herbaceous understory plants or to leaf litter derived from plants of different ontogenetic stages. Thus, through a field study on the microbial decay of leaf litter from woody versus herbaceous and immature versus mature plants, we test the hypotheses that (1) the initial chemical composition of the leaf litter of different species and maturity stages will determine decay processes; and (2) the microbial community engaged in decay will respond to the changes in leaf chemistry during decay by altering the activity of extracellular enzymes to break down recalcitrant litter compounds. We expect the findings of this study to contribute to our understanding of organic matter dynamics in mangrove stands of different compositions and ages, and thus, to develop into implications for mangrove management.

\section{Methods}

\section{Study area and species}

This study was conducted in the Matang Mangrove Forest Reserve (MMFR), located at the border of the Straits of Malacca on the northwest coast of Peninsular Malaysia (Fig. S1.1). The MMFR is a riverine mangrove forest that covers about 40,288 ha and is home to at least 27 mangrove species (Hamdan et al. 2014; Otero et al. 2019). However, more than $80 \%$ of the total area is occupied by the two commercially exploited species Rhizophora apiculata Blume and
Rhizophora mucronata Lamk. (Ariffin and Nik Mohd Shah, 2013). The climate of the MMFR is year-round warm humid, with rainfall ranging from 2000 to $2800 \mathrm{~mm}_{\text {year }}{ }^{-1}$, average air temperature ranging from a maximum of $33^{\circ} \mathrm{C}$ during the day to a minimum of $22{ }^{\circ} \mathrm{C}$ at night, and the relative humidity averaging $99 \%$ in the early morning and $60 \%$ at midday (Muda and Mustafa 2003). The area is subjected to semidiurnal tides with the tidal amplitude range of 1.6-3 m (Goessens et al. 2014).

The decay experiment was performed near the Matang Mangrove Eco-Education Centre (45ㅇ'31.4" N $100^{\circ} 38^{\prime} 08.2^{\prime \prime} \mathrm{E}$ ), at a site that had been reserved for educational purposes since 1998. Mangrove species other than Rhizophora spp. had been planted there to increase plant diversity. In 2020, the age of the mangrove forest in this area is estimated as 42 years. The selected mangrove species were the dominant species in the study area, which were divided into two categories: woody versus herbaceous plants, namely Rhizophora apiculata Blume and Bruguiera parviflora (Roxb.) Wight \& Arn. ex Griff versus Acrostichum aureum L. and Acanthus ilicifolius L., respectively. Henceforth these species will be referred to by genus name.

\section{Experimental setup}

Leaf litter decay was studied using litterbags with leaf litter from two ontogenetic stages of the above four species. Immature plants were identified by the absence of reproductive parts (e.g. flowers, propagules, fruits, fertile leaves with sporangia) and by the size and the volume of the plant, assuming these features are correlated with age (Sharpe and Mehltreter 2010). Mature plants were identified otherwise (e.g. diameter at breast height more than $20 \mathrm{~cm}$ for woody plants, higher plant volume for herbaceous plants and presence of reproductive parts). Yellowish senescent leaves for the experiment were either freshly fallen or easily handpicked from the plants in the surrounding area. As senescent leaves of A. aureum are non-abscising, we hand-picked senescent leaflets (instead of entire fronds) from the plants.

Fresh senescent leaves were used in the litter decay experiment, as pre-drying accelerates the initial rate of mass loss through leaching (Ananda et al. 2008) and affects microbial activity. Twelve senescent leaves per bag were cut in half along the midrib and both halves were weighed. One half of each leaf was brought to the laboratory to obtain the dry:fresh weight ratio and the second half was utilized for the litterbag experiment. Litterbags were made of glass fibre mesh $\left(200 \mathrm{~mm} \times 200 \mathrm{~mm}\right.$, mesh size $\left.1 \mathrm{~mm}^{2}\right)$ and closed using polypropylene clips. The litterbag experiment started in November 2018 and lasted for 70 days, with an intermediate sampling of litterbags after 14 and 35 days. Another set of senescent leaves was sampled separately for determining initial leaf litter characteristics. 
Seven replicate plots of $20 \mathrm{~m}$ diameter were distributed over an experimental site of $100 \mathrm{~m} \times 100 \mathrm{~m}$, with minimum distance among plots of $20 \mathrm{~m}$ (Fig. S1.2). The sediment of the MMFR is generally sulphur-rich (Priya et al. 2018) and fine-grained. Sediment $\mathrm{pH}$, organic carbon content and total nitrogen content of this one-hectare site were $5.5 \pm 0.5$ $(n=7), 15 \pm 5 \%$ and $0.6 \pm 0.2 \%(n=3)$, respectively. Litterbags were randomly placed at each plot on the sediment surface. On each sampling date, 56 litterbags of different species and ontogenetic stages were removed from the field and brought to the laboratory of the Biology Department of the Faculty of Science and Technology of the National University of Malaysia (FST UKM) for sample treatment and analysis.

The reduction of leaf litter mass over time was measured to obtain decay constants $(k)$, leaf half-life $\left(\mathrm{t}_{0.50}\right)$, and $95 \%$ and $99 \%$ lifespan $\left(\mathrm{t}_{0.95}\right.$ and $\left.\mathrm{t}_{0.99}\right)$ (Eq. 1-4). Leaf material was cleaned carefully with a brush and tap water, then freezedried (Christ 1-2 LD Plus), and the final dry weight was recorded. Based on the dry:fresh weight ratio of the retained half leaves, their initial dry weight $\left(\mathrm{X}_{\mathrm{o}}\right)$ was estimated, and the difference to the remaining dry weight obtained from the litterbags after 14, 35 and 70 days (t) was used as mass loss upon decay $\left(\mathrm{X}_{\mathrm{t}}\right)$.

$X_{t}=X_{o} e^{-k t}$

$t_{0.50}=\frac{\ln (2)}{k}=\frac{0.6931}{k}$

$t_{0.95}=\frac{3}{k}$

$t_{0.99}=\frac{5}{k}$

\section{Laboratory analyses}

All laboratory analyses carried out in this study are summarized in Fig. S1.3. Fresh leaf litter subsamples were subjected to the measurement of microbial extracellular enzyme activities. Samples were weighed corresponding to $50-100 \mathrm{mg}$ dry weight and cut into small pieces before they were homogenized with a tissue-tearer homogenizer (Dremel 395 MultiPro) in $10 \mathrm{~mL}$ of $0.10 \mathrm{M} \mathrm{Na}-\mathrm{K}$ phosphate buffer on ice. Enzyme extraction was performed at $(24 \pm 2){ }^{\circ} \mathrm{C}$ for $1 \mathrm{~h}$ in a rotary mixer (Elmi Intelli-Mixer $\mathrm{RM}-2 \mathrm{~L}$ ) at $90 \mathrm{rpm}$. The homogenates were centrifuged for 5 min, with $4000 \mathrm{~g}$ at $4{ }^{\circ} \mathrm{C}$. The obtained supernatants were directly analysed or kept refrigerated $\left(4{ }^{\circ} \mathrm{C}\right)$ until analysis within a few days. The enzymatic activity assays were analysed by UV-Vis spectrophotometer (Shimadzu UV-1800).
Phenol oxidase activity was determined through the spectrophotometric determination of 4-( $\mathrm{N}$-proline)-o-benzoquinone resulting from enzymatic oxidation of catechol as the substrate in the presence of L-proline (adopted from Zimmer 2005b; Perucci et al. 2000). Upon mixing of $200 \mu \mathrm{L}$ sample supernatant, $900 \mu \mathrm{L} 0.05 \mathrm{M} \mathrm{L}$-proline and $900 \mu \mathrm{L}$ $0.05 \mathrm{M}$ pyrocatechol, absorbance changes $(\Delta A)$ at $520 \mathrm{~nm}$ was recorded at 1-min intervals over $10 \mathrm{~min}$. Relative catechol oxidation was determined as the slope of $\Delta A$ produced by linear regression analysis. Phenol oxidase activity was expressed as relative phenol oxidation capacity (RAU $\left.\mathrm{g}^{-1} \mathrm{~h}^{-1}\right)$.

Cellulase activity was quantified according to Zimmer (2005a), Skambracks and Zimmer (1998) and Linkins et al. (1990) with some modifications. A mix of $90 \mathrm{mg} \alpha$-cellulose, $900 \mu \mathrm{L}$ supernatant solution and $900 \mu \mathrm{L}$ citrate-phosphate buffer (with $0.05 \% \mathrm{NaN}_{3}$ ) was incubated in a rotary mixer for 18 to $24 \mathrm{~h}$ and then centrifuged for $15 \mathrm{~min}$ at $1000 \mathrm{~g}$ at room temperature. Blank solutions were prepared by mixing $700 \mu \mathrm{L}$ supernatant with $300 \mu \mathrm{L}$ citrate-phosphate buffer and measured at $340 \mathrm{~nm}$ to obtain absorbance at time zero $\left(\mathrm{A}_{0}\right)$. For samples, $700 \mu \mathrm{L}$ supernatant was mixed with 300 $\mu \mathrm{L}$ glucose (HK) assay kit solution (Sigma-Aldrich), incubated for $15 \mathrm{~min}$ at room temperature, and then the absorbance was measured $\left(A_{15}\right)$ at $340 \mathrm{~nm}$. The final absorbance was calculated by subtracting $\mathrm{A}_{0}$ from $\mathrm{A}_{15}(\Delta \mathrm{A})$.

Protease activity was determined through enzymatic decay of azocasein as a chromogenic protein substrate (after de Menezes et al. 2014; Charney and Tomarelli 1947). A mix of $500 \mu \mathrm{L}$ supernatant solution and $500 \mu \mathrm{L} 1 \%$ azocasein solution was incubated at room temperature for $1 \mathrm{~h}$ in a rotary mixer at $90 \mathrm{rpm}$. The proteolytic reaction was stopped by adding $500 \mu \mathrm{L} 20 \%$ TCA to precipitate the remaining substrate. Then, the mixture was kept on ice for $10 \mathrm{~min}$ and centrifuged at $1000 \mathrm{~g}$ for $15 \mathrm{~min}$ at room temperature. For the blank solution, 20\% TCA was added before the addition of sample supernatant. Both sample and blank solutions were alkalinized with an equal volume of $2 \mathrm{M} \mathrm{NaOH}$ solution prior to the photometric measurement at $440 \mathrm{~nm}$. As the proteolysis of azocasein results in a mix of peptides and amino acids, the final result was expressed as relative protease activity (RAU g ${ }^{-1} \mathrm{~h}^{-1}$ ).

For leaf chemistry analyses -total carbon content, total nitrogen content, total phenolic content, protein-precipitation capacity and phenolic fingerprint- samples were shipped to the Leibniz Centre for Tropical Marine Research (ZMT), Bremen, Germany.

Approximately 1 to $2 \mathrm{~g}$ sub samples of fine-ground leaflitter were weighed and encapsulated in $10 \times 10 \mathrm{~mm}$ tin capsules for the measurement of carbon and nitrogen contents (Eurovector EA3000 Elemental Analyzer). Birch leaf standard (BLS) was used as standard. Another $50 \mathrm{mg}$ of the samples were extracted with $2 \mathrm{~mL}$ of $70 \%$ ethanol at room 
temperature for $1 \mathrm{~h}$ with a rotary mixer at $90 \mathrm{rpm}$, and then the supernatants were separated from the precipitates by centrifugation at $10,000 \mathrm{~g}, 4{ }^{\circ} \mathrm{C}$ for $10 \mathrm{~min}$.

The total phenolic content was determined following the Folin-Ciocalteu assay (Bärlocher and Graça 2005; Ainsworth and Gillespie 2007). Aliquots of 10 to $200 \mu \mathrm{L}$ of the supernatants were diluted to $500 \mu \mathrm{L}$ with double-distilled water. Then, $250 \mu \mathrm{L} 1 \mathrm{~N}$ Folin-Ciocalteu reagent and $1.25 \mathrm{~mL} 700 \mathrm{mM} \mathrm{Na}_{2} \mathrm{CO}_{3}$ were added sequentially and the final solutions were vortexed. Blanks contained $500 \mu \mathrm{L}$ double-distilled water but no sample. The mixture was kept in the dark for $1-2 \mathrm{~h}$, before the absorbance was read at $750 \mathrm{~nm}$ using a microplate reader (TECAN Infinite M200 Pro). Tannic acid served as standard, and results are expressed as $\mathrm{mg}$ tannic acid equivalents (TAE) $\mathrm{g}^{-1}$ litter.

The protein-precipitation capacity of the leaf litter phenolics was quantified through a radial diffusion assay, using bovine serum albumin $(0.1 \%$ in ascorbic acid-containing agarose) as protein (Graça and Bärlocher 2005; Hagerman 1987). Four consecutive $9 \mu \mathrm{L}$ aliquots from each supernatant were added to a single $2 \mathrm{~mm}$ well in the agarose gel plate. Each plate contained three tannic acid standards of 0.09 , 0.18 and $0.27 \mathrm{mg} \mathrm{mL}^{-1}$. The gel plates were incubated for 3 to 4 days at room temperature. Then, the average of two perpendicular diameters of protein precipitation rings from both standards and samples was determined using a stereomicroscope. The ring area was calculated after subtracting the diameter of the wells. Protein-precipitation capacity is expressed in TAE $\mathrm{g}^{-1}$ sample dry weight.

As the Folin-Ciocalteu and the radial diffusion assays provide different proxies for the phenolic signature of a sample (Zimmer et al. 2015), a phenolic fingerprint was additionally depicted through HPLC analysis of litter sample extracts. The supernatants of these extracts were dried in a multievaporator system (Heidolph Synthesis 1) for approximately $1 \mathrm{~h}, 1000 \mathrm{rpm}, 60^{\circ} \mathrm{C}$. The pressure was set to $175 \mathrm{mbar}$ for $30 \mathrm{~min}$ to evaporate ethanol and changed to $60 \mathrm{mbar}$ to evaporate water. The dried extracts were dissolved with $2 \mathrm{~mL}$ acetonitrile mix reagent (23\% acetonitrile: $76 \%$ water: $1 \%$ acetic acid $\mathrm{v} / \mathrm{v}$ ) in an ultrasonic bath for $10 \mathrm{~min}$ and filtered through $0.45 \mu \mathrm{m}$ PTFE filters. The sample solutions were placed in $1.0 \mathrm{~mL}$ glass vials and kept frozen at $-24^{\circ} \mathrm{C}$ until analysis. Individual phenolic fingerprints of litter samples were obtained through reverse-phase high-performance liquid chromatography (Agilent 1260 Infinity), with a Luna $5 \mu \mathrm{m} \mathrm{C18(2)} \mathrm{non-polar} \mathrm{column}(100 \AA, 250 \times 4.6 \mathrm{~mm})$ and detected at $280 \mathrm{~nm}$ with a Diode Array Detector. Flow-rate was kept at $1.25 \mathrm{~mL} / \mathrm{min}$, and temperature was set to $20^{\circ} \mathrm{C}$. From each sample, $20 \mu \mathrm{L}$ was injected. The elution condition of the binary pump was: $0-11 \mathrm{~min}, 100 \%$ A (isocratic); 11-27.5 min, 75\% A (linear gradient); 27.5-28.5 min, 0\% A (linear gradient; $28.5-31 \mathrm{~min}, 0 \% \mathrm{~A}$ (isocratic); 31-32 min, $100 \%$ A (linear gradient); 32-35 min, 100\% A (isocratic), with solvent A: $18 \%$ acetonitrile: $0.5 \%$ acetic acid:81.5\% water; solvent B: $100 \%$ acetonitrile. Gallic acid, tannic acid and sinapyl alcohol, a monomer of many lignins, served as standards for the identification and quantification of some of the resulting peaks.

Data and statistical analyses were conducted using the statistical package $\mathrm{R}$ version 3.4.4 (R Core Team 2018) and PAST software version 3.25 (Hammer et al. 2001). Normality of data was tested through Shapiro-Wilk's tests and data were square root-transformed prior to the statistical analysis where necessary. The effects of ontogenetic and interspecific differences on leaf decay, leaf chemistry and extracellular enzyme activity over time were analysed through repeated measures analysis of variance (RM ANOVA) with fixed variations of species (4 levels), maturity stages (2 levels) and time intervals (4 levels). Bonferroni tests were used for post-hoc analyses $(\alpha=0.05)$. Correlation coefficient matrices were created to determine the relationship of the leaf litter decay rate, represented as leaf half-life $\left(t_{0 \cdot 50}\right)$, with initial leaf chemistry and extracellular enzymatic activity variables.

Differences in phenolic fingerprints (HPLC analysis) were visualized through non-metric multidimensional scaling (NMDS) with Morisita-Horn similarity index (Magurran 2004). Non-parametric permutational multivariate ANOVA (PERMANOVA) with 9999 permutations was utilized to test for significance of interspecies and ontogenetic differences, based on the selected distance measure (Anderson 2001). Similarity Percentage (SIMPER) analysis was used for assessing which HPLC peaks (= phenolic compounds) were primarily responsible for an observed difference among groups of samples (Clarke 1993).

\section{Results}

\section{Leaf litter decay}

Leaf litter of all species exhibited an initial rapid mass loss during the first 14 days, followed by a slower mass loss during the following weeks (Fig. 1). Interspecific differences in the mass loss were more pronounced in the leaf litter of immature than mature plants. At the end of the decay experiment, the remaining mass proportion of Acanthus litter ( $4 \pm 4 \%$ of initial mass) was significantly lower than of the other species, while the remaining mass proportion of Acrostichum litter was significantly higher than of the other species, especially for immature plants $(57 \pm 8 \%)$. The mass loss of Rhizophora and Bruguiera litter was more moderate than for the herbaceous species, with litter from immature Rhizophora ( $25 \pm 5 \%$ remaining) decayed significantly faster than litter from immature Bruguiera $(40 \pm 8 \%)$ and mature Rhizophora $(36 \pm 5 \%)$. Decay patterns of all litter types fitted a single negative exponential model $\left(R^{2}>0.8\right)$ 


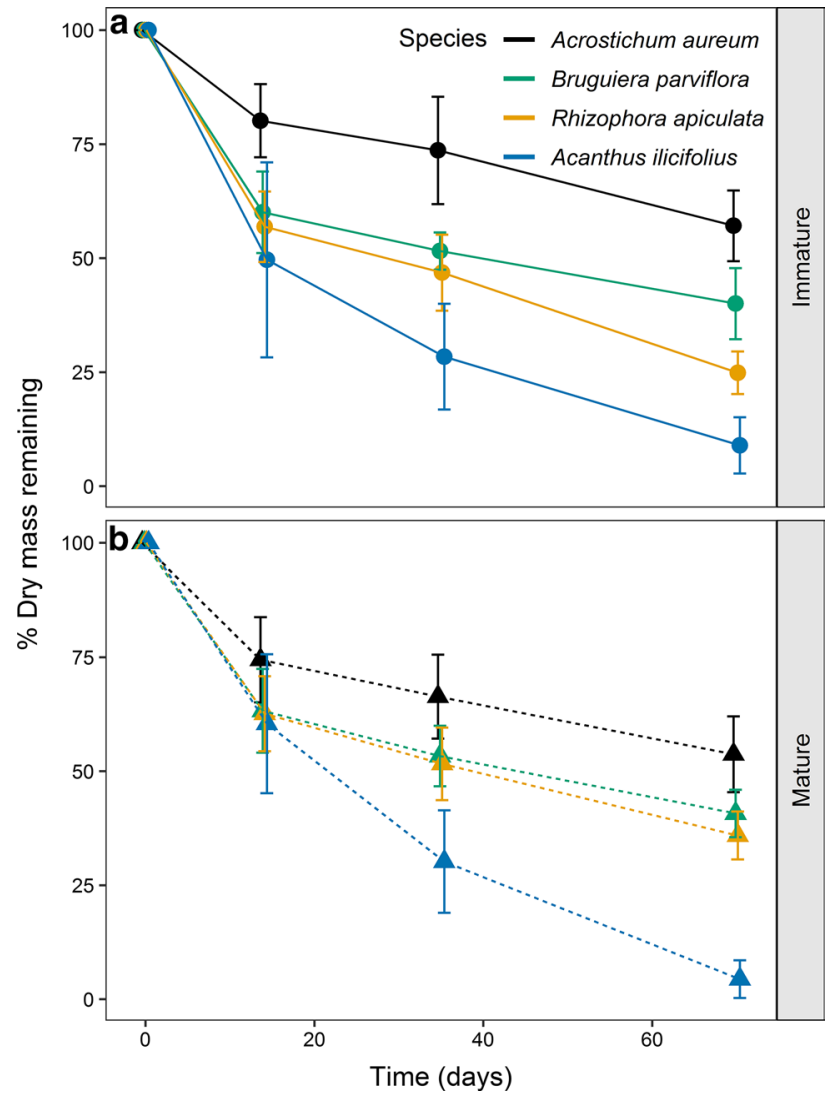

Fig. 1 Remaining dry mass of leaf litter of different ontogeny and species overtime during the leaf litter decay experiments. Leaf litter decay ordered from the slowest to the fastest were Acrostichum aureum (black), Bruguiera parviflora (green), Rhizophora apiculata (yellow) and Acanthus ilicifolius (blue); a immature plants: circles; b mature plants: triangles. Error bars represent the 95\% confidence interval of the mean $(n=224)$

(Table 1). Litter of both immature and mature Acrostichum were projected to lose $99 \%$ of its mass after $\sim 650$ days, while
Acanthus litter was projected to only need less than 5 months to decay almost completely (Table 1).

Species differed significantly from each other with respect to mass-loss rates $(p<0.0001 ;$ RM ANOVA: Table S2.1). We did not detect the overall effects of the ontogenetic stage, but upon within-species comparison, the litter of mature Rhizophora was projected to take about $40 \%$ longer to decay by $99 \%$ than that of immature Rhizophora (Table 1). According to a significant interaction of species $\mathrm{x}$ maturity $(p=0.028)$, the decay patterns of different ontogenetic stages changed over time.

\section{Leaf litter chemistry}

Litter carbon contents generally increased from the initial stage (Day 0) to the end (Day 70) of the decay experiments, except for Acanthus litter that exhibited decreased $\mathrm{C}$ contents after 70 days (Fig. 2a). The initial carbon contents of litter from immature Rhizophora plants were significantly lower than from mature Rhizophora plants. The litter with the highest initial carbon content was that of immature Bruguiera (48.1 $\pm 0.6 \%)$; litter of immature Acanthus had the lowest $\mathrm{C}$ content $(40 \pm 5 \%)$. We observed a significant interspecific differences of carbon contents ( $p=0.011$; RM ANOVA) (Table S2.2). Nitrogen contents of litter from immature plants were generally higher than those of litter from mature plants, being significantly different in Rhizophora and Acrostichum litter (Fig. 2b). The nitrogen contents of all species and ontogenetic stages increased significantly over the decay experiment $(p<0.0001)$ (Table S2.3).

Accordingly, initial C: $\mathrm{N}$ ratios of litter from immature Rhizophora and Acrostichum plants were significantly lower than from their mature plants (Fig. 2c). By the end of the decay experiment, the $\mathrm{C}: \mathrm{N}$ ratio of all species and maturity stages had significantly decreased, except for litter from immature Acrostichum. The lowest initial C:N ratio was found in litter from immature Acrostichum (27 \pm 3 ) and the highest in litter from mature Bruguiera $(97 \pm 20)$. In general,

Table 1 Decay constant $(\mathrm{k})$, half-life $\left(t_{0.50}\right), 95 \%$ and $99 \%$ lifespan $\left(t_{0.95}\right.$ and $\left.t_{0.99}\right)$ of different mangrove species and maturity stages obtained from negative single exponential equations

\begin{tabular}{|c|c|c|c|c|c|c|c|}
\hline Species name & Maturity stages & $R^{2}$ & Intercept & $\begin{array}{l}\text { Decay constant } \\
-\mathrm{K}\left(\mathrm{day}^{-1}\right)\end{array}$ & $t_{0.50}$ (days) & $\mathrm{t}_{0.95}$ (days) & $\mathrm{t}_{0.99}$ (days) \\
\hline \multirow[t]{2}{*}{ Rhizophora apiculata } & Immature & 0.950 & 87.649 & 0.0184 & 38 & 163 & 272 \\
\hline & Mature & 0.918 & 87.014 & 0.0134 & 52 & 224 & 373 \\
\hline \multirow[t]{2}{*}{ Bruguiera parviflora } & Immature & 0.839 & 83.835 & 0.0116 & 60 & 258 & 430 \\
\hline & Mature & 0.876 & 85.951 & 0.0116 & 60 & 259 & 431 \\
\hline \multirow[t]{2}{*}{ Acrostichum aureum } & Immature & 0.956 & 95.044 & 0.0074 & 93 & 403 & 672 \\
\hline & Mature & 0.905 & 91.322 & 0.0081 & 86 & 370 & 617 \\
\hline \multirow[t]{2}{*}{ Acanthus ilicifolius } & Immature & 0.991 & 90.371 & 0.0333 & 21 & 90 & 150 \\
\hline & Mature & 0.984 & 112.81 & 0.0445 & 16 & 67 & 112 \\
\hline
\end{tabular}


Fig. 2 Mangrove leaf litter chemistry of a Total carbon contents, $\mathbf{b}$ total nitrogen contents, and $\mathbf{c}$ carbon-to-nitrogen (C:N) ratio of leaf litter from immature (circles) and mature (triangles) plants during the initial and final days of the decay experiment. Mangrove species Rhizophora apiculata, Bruguiera parviflora, Acrostichum aureum, and Acanthus ilicifolius are identified by their genus name. Error bars indicate 95\% confidence interval of the mean $(n=112)$
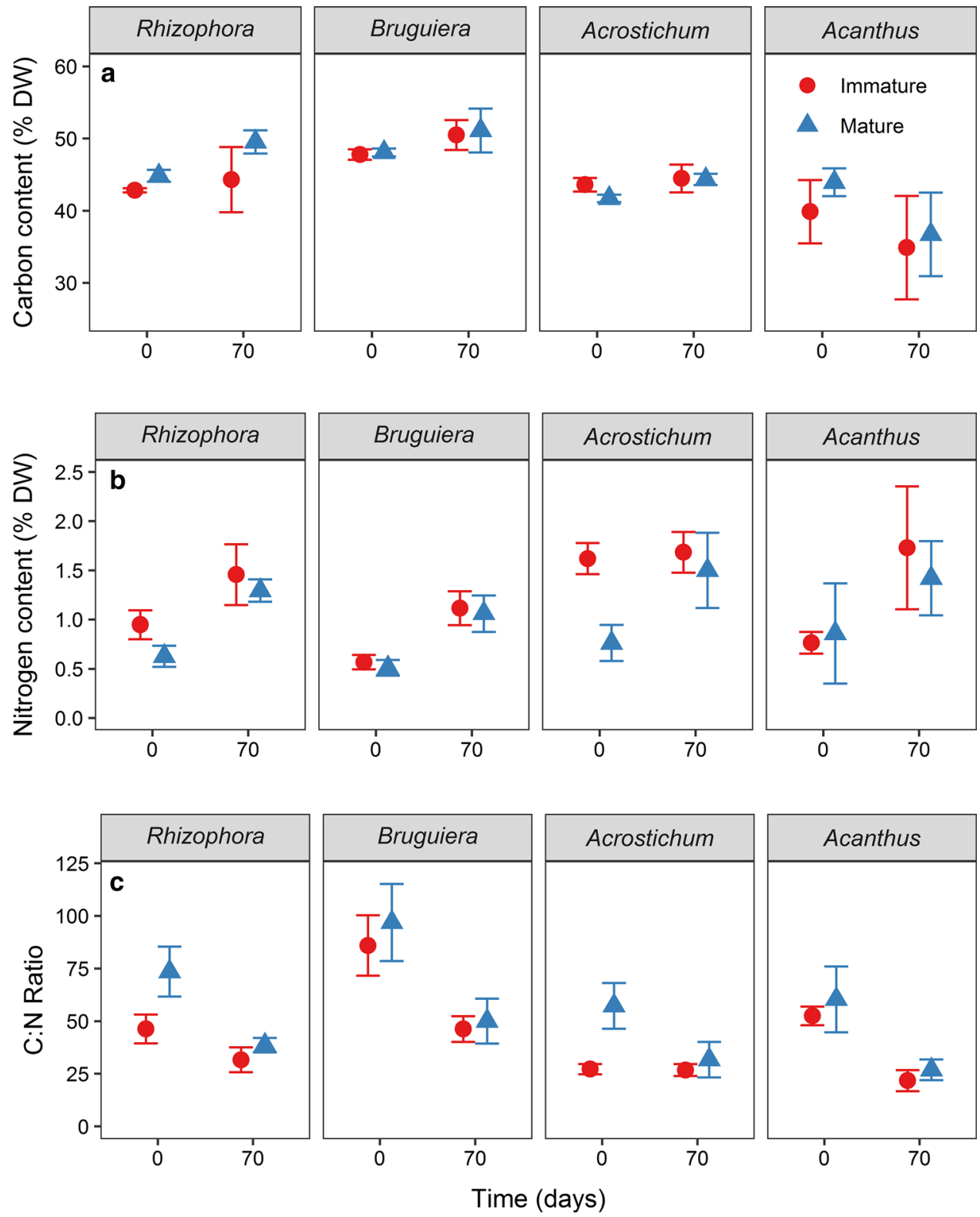

$\mathrm{C}: \mathrm{N}$ ratios differed significantly among species and over time $(p<0.0001)$ (Table S2.4).

Bruguiera litter was characterized by the highest content of phenolic compounds, followed by Rhizophora, Acrostichum and Acanthus (Fig. 3a). Litter of immature plants generally contained less phenolics than that of mature plants, but these differences were significant only for Acrostichum litter (Bonferroni post-hoc test $p<0.0001$ ). The highest phenolic content was exhibited in senescent leaves (Day 0) and gradually decreased over time of decay. After 14 days of experiments, the phenolics were reduced sharply to around $20 \%$ or less of the initial contents. Significant interactions between species $\mathrm{x}$ time and maturity x time (Table S2.5) suggest species- and stage-specific patterns of changes in the phenolic contents.
Similar to the phenolic content, the protein-precipitation capacity of phenolic compounds was the highest in senescent leaves (Day 0) and steadily decreased over time (Fig. 3b). The litter of Bruguiera and Rhizophora had significantly higher protein-precipitation capacity than Acanthus litter, which exhibited no protein-precipitation capacity throughout the study. While the initial protein-precipitation capacity dropped drastically within the first days (Bonferroni post-hoc test $p<0.0001$ ), there were no significant further changes during later phases of the experiment $(p>0.5)$ (Table S2.6).

HPLC analysis of phenolic signatures distinguished 38 peaks, representing unique phenolic compounds and their isomers (Figs. S3.1 and S3.2). Some of these peaks indicated specific biomarkers for either species or ontogenetic stages. 

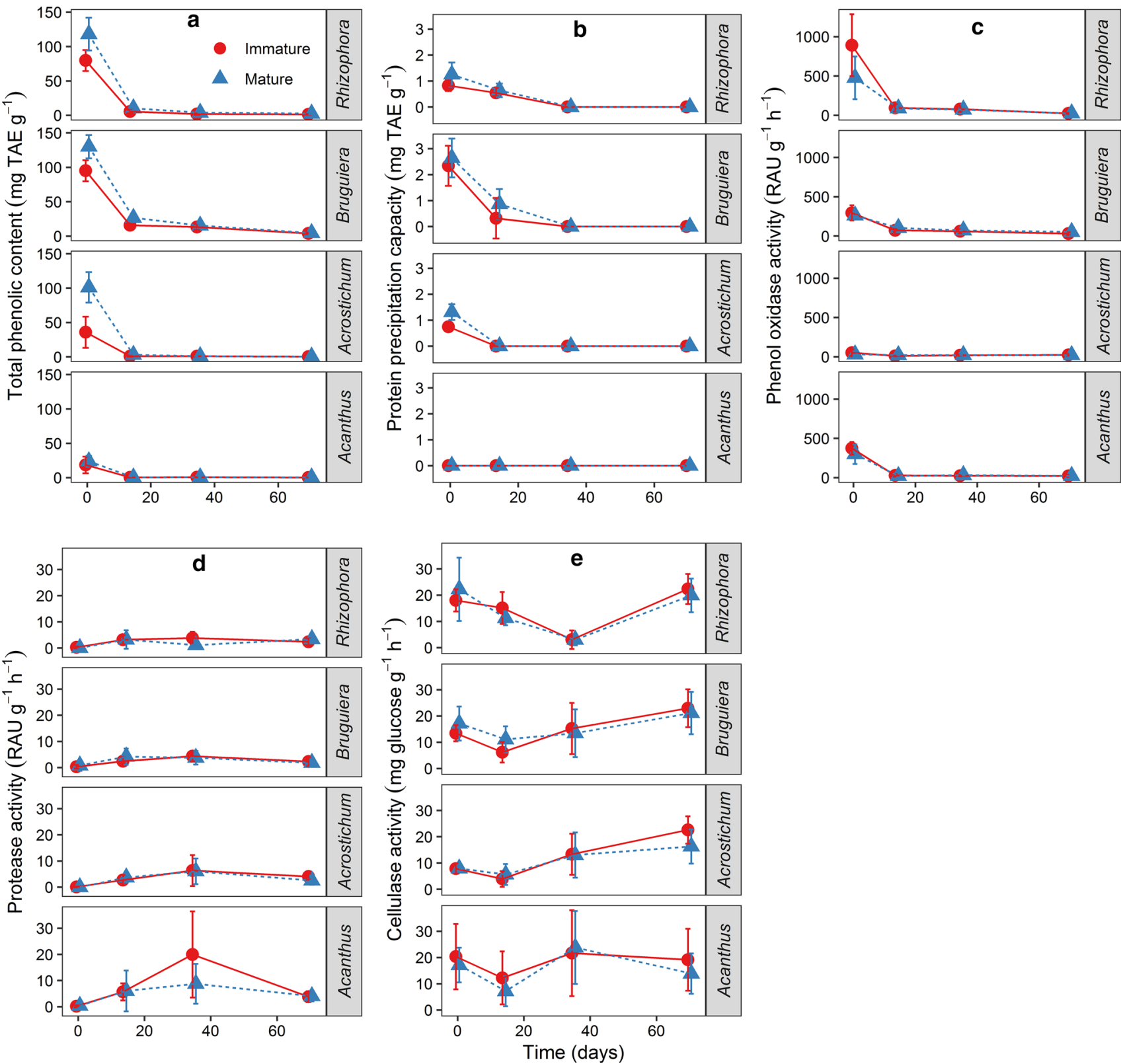

Fig. 3 a Total phenolic contents, b protein precipitation capacity, c phenol oxidase, $\mathbf{d}$ protease, and e cellulase enzyme activity of mangrove leaf litter with different maturity stages and species at differ-

ent time intervals $(0,14,35$, and 70 days); immature plants: circles; mature plants: triangles. Error bars indicate $95 \%$ confidence interval of the mean $(n=224)$

9 was high in Rhizophora, Bruguiera, and Acrostichum litter but low in Acanthus that, in turn, was uniquely characterized by Peak 10 and 26 (7.2 and 4.4\% contribution). Peak 26 was high in the herbaceous Acrostichum and Acanthus but low in the arboreal Rhizophora and Bruguiera.

Aiming at assigning these peaks to particular phenolic compounds, we used tannic acid and its monomer gallic acid, and the lignin monomer sinapyl alcohol, as well as D-glucose as one of the most common components of sugar esters in tannic acid and other compounds, as standards. 
Peak 6, 11, 22 and 28 are the major peaks (Table S3.1), of which Peak 6 represents gallic acid, of the complex mix of tannic acid. Sinapyl alcohol is reflected by Peak 20, while Peak 8 represents D-glucose.

According to the above standard compounds, the major phenolic difference between Acanthus and the other species was the lack of gallic acid and its galloyl esters. The diversity of phenolic compounds in Rhizophora leaves was low and characterized by a lack of compounds with higher retention times, possibly reflecting compounds with low hydrophilicity. The relative contribution of different phenolic compounds was significantly different among both species and ontogenetic stages (PERMANOVA: $p<0.001$ ) (Table 2). The significant interaction between species $\mathrm{x}$ maturity indicates species-specific effects of the ontogenetic stage on the phenolic signature.

\section{Extracellular enzyme activity}

Phenolic contents of litter were highest, and phenol oxidases exhibited the highest activities, during the initial stage of decay, and both constantly decreased over time (Fig. 3c). Phenol oxidase activity changed significantly over time within species (RM ANOVA $p<0.0001$ : Table S2.7). The activity of phenol oxidases was highest in Rhizophora litter, and higher in litter from mature than immature plants (Bonferroni post-hoc test $p=0.0003$ ). Significant ontogenetic differences were also found in Bruguiera litter $(p<0.0001)$.

Hardly any protease activity was detectable at Day 0 (Fig. 3d), being lower in Rhizophora and Bruguiera than in Acrostichum and Acanthus litter $(p<0.0001)$. The ontogenetic stage had a significant influence $(p=0.005)$, too, and protease activity changed significantly over time, generally peaking at Day 35 (Table S2.8).

Cellulase activity decreased over the first 14-35 days and then generally increased again until the end of the experiment (Fig. 3e). By contrast, the decreasing cellulase activity in Acanthus litter may be attributed to the high

Table 2 PERMANOVA results of the effects of interspecific and ontogenetic (maturity stages) differences on the phenolic signatures of mangrove leaf litter

\begin{tabular}{llllll}
\hline $\begin{array}{l}\text { Source of dif- } \\
\text { ference }\end{array}$ & $\begin{array}{l}\text { Sum of } \\
\text { squares }\end{array}$ & $d f$ & Mean square & $F$ & $P$ value \\
\hline Species & 1.7755 & 3 & 0.59183 & 23.277 & $<0.001$ \\
Maturity & 0.15795 & 1 & 0.15795 & $6.2122<0.001$ \\
Interaction & 0.38644 & 3 & 0.12881 & $5.0663<0.001$ \\
Residual & 1.2459 & 49 & 0.025426 & & \\
Total & 3.5658 & 56 & & & \\
\hline
\end{tabular}

mass loss of litter from this species. Differences among ontogenetic stages were negligible (Table S2.9).

\section{Discussion}

Mass loss, as well as chemistry and enzyme activities, of litter from different species and ontogenetic stages of mangrove plants changed over time upon microbial decay following the typical three phases of decay, namely leaching, fragmentation and degradation phases (Zimmer 2019). Overall, litter half-life was positively correlated with total phenolic content and protein-precipitation capacity, and negatively correlated with phenol oxidase and cellulase activity. Many studies relate high decay rates to low $\mathrm{C}: \mathrm{N}$ ratio (high $\mathrm{N}$ content) and low contents of lignins and cellulose (e.g. Hernes et al. 2001; Bosire et al. 2005), but these variables did not exhibit any significant effect on decay rates in the present study. Thus, leaf phenolics slowed down litter decay, while the microbial activity of phenol oxidases and cellulases accelerated decay processes, and these parameters may prove better predictors of decay rates of mangrove litter than those mentioned before. Hence, our study supports the hypothesis of Cotrufo et al. (2013) that plant litter with high contents of labile low-molecular weight compounds is utilized more efficiently by microbes than recalcitrant plant litter. During decay processes, microbial immobilization of $\mathrm{N}$ into biomass, together with more excessive leaching of $\mathrm{C}$ - than $\mathrm{N}$-containing compounds, results in (relative) increase in the litter $\mathrm{N}$ content over time (Schimel and Bennett 2004). In the present study, the $\mathrm{N}$ contents of all species and ontogenetic stages increased over the 70 days of the experiment. Substrates with a low $\mathrm{C}: \mathrm{N}$ ratio (i.e., relatively higher $\mathrm{N}$ content) generally support higher microbial abundances and higher microbial decay rates (Bouillon et al. 2004; Manzoni et al. 2008). While it was previously assumed that the accumulation of recalcitrant litter contributes more to organic matter formation in sediment than labile fast-decaying litter (e.g. Freschet et al. 2012), our results suggest that labile litter is the dominant source of microbial products that, in turn, are the largest contributor to the build-up of sediment organic matter (Gleixner 2013; Cotrufo et al. 2013).

Our quantitative proxies of the phenolic signature of the litter were correlated negatively with $\mathrm{N}$ and positively with C (Fig. 4). This observation is consistent with the two strategies of resource allocation of plant defence against herbivory and pathogens, either by producing highly recalcitrant C-rich compounds, such as phenolics and terpenoids or by producing N-rich compounds, such as alkaloids and glucosinolates, that are often not recalcitrant but deterrent or toxic (Wittstock and Gershenzon 


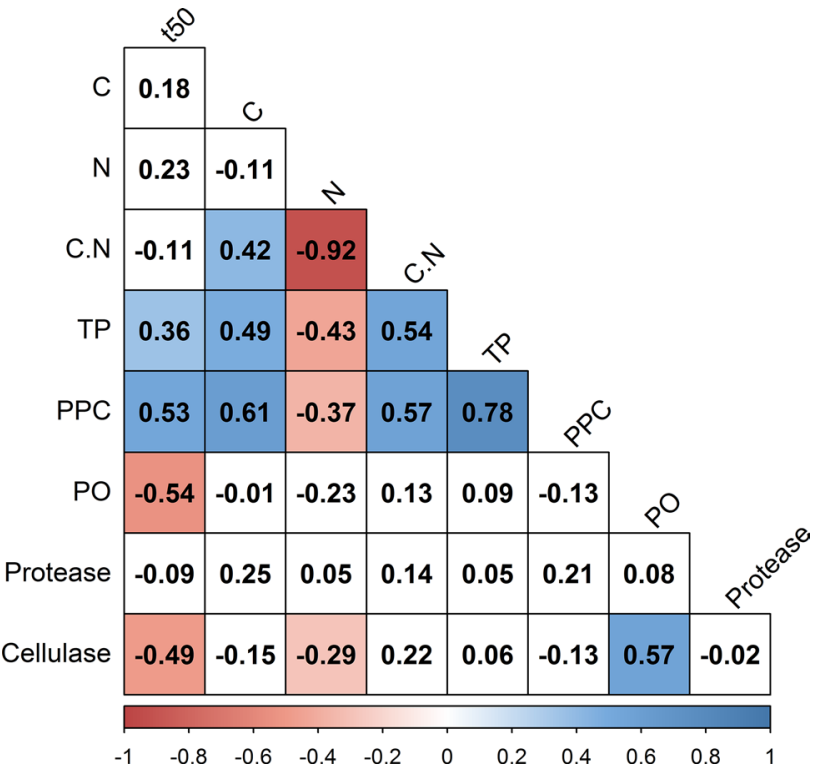

Fig. 4 Heat map of correlation coefficients between litter half-life $\left(t_{0.50}\right)$ and initial litter characteristics. Variables that correlate significantly at $\alpha=0.05$ are marked blue for positive and red for negative correlation $(n=56)$. Fields with non-significant correlation coefficients are left blank. $C$ carbon, $N$ nitrogen, $C . N C$-to-N ratio, $T P$ total phenolics, $P P C$ protein precipitation capacity, $P O$ phenol oxidase

2002; Schultz et al. 2013). From our observation, it is possible that the allocation of defence chemicals as either $\mathrm{C}$-rich compounds or N-rich compounds changes during the ontogenetic development in mangrove species, and thus, differs between immature and mature plants. Therefore, understanding differences and changes in allocation strategies is relevant to predict organic matter turnover and dynamics which, in turn, are key elements of storing climate-active gases in sediment organic matter ("blue carbon").

Phenol oxidase activity on litter from all plant species and ontogenetic stages showed a significant decrease over the time of decay, along with the leaching-driven decrease in phenolic content. Microbial enzymes, such as phenol oxidase and cellulases, are the major drivers of decay (Allison et al. 2007; Sinsabaugh et al. 2008). The activities of phenol oxidases and cellulases were positively correlated with each other, suggesting synergistic action during microbial decay, as some phenolics are bound to cellulose and other plant polymers (Zhou et al. 2012). On the other hand, both enzyme activities were negatively correlated with the $\mathrm{N}$ content, corroborating the observation of Saiya-Cork et al. (2002) in terrestrial forests that the decomposition of recalcitrant soil organic matter is inhibited by $\mathrm{N}$ in the environment, possibly through a reduced need for degrading macromolecules when $\mathrm{N}$ is available. This correlation might help explain that the influence of
$\mathrm{N}$ content or $\mathrm{C}: \mathrm{N}$ ratio on decay rates was much weaker (and non-significant) than that of phenolic contents and the activities of cellulases and phenol oxidases.

The initial leaching of soluble compounds resulted in a rapid reduction of litter mass, content of phenolics, proteinprecipitation capacity and phenol oxidase activity during the first days of decay ( $\mathrm{Li}$ and Ye 2014; Zimmer 2019). The release of soluble compounds into the sediment (porewater) results in an accumulation of insoluble, i.e., recalcitrant high-molecular-weight compounds, such as condensed tannins, cellulose and lignins, in the litter. When the lignin content of litter is below $10 \%$, other factors limit decay, but at lignin contents of above $28 \%$, decay rates will be uniformly low because of the recalcitrant nature of lignins (Prescott 2005). Thus, while N-immobilization accelerates decay, the accumulation of recalcitrant $\mathrm{C}$-rich compounds slows down decay and results in a shift of the microbial community from generalists towards specialists (Das et al. 2007).

Microbial colonization commences long before leaf abscission, essentially by microbial endophytes or pathogens of the living leaf (Hardoim et al. 2015). Especially pathogenic fungi colonizing photosynthetically active leaves might, thus, be responsible for high initial phenol oxidase and cellulase activities (Arfi et al. 2012) and contribute to initial microbial decay processes. The increase in protease activity of the first 2-3 weeks of decay suggests an increase of protein substrates, such as in microbial biomass upon $\mathrm{N}$-immobilization, as many fungi produce particular enzymes only upon demand, i.e., when required for particular substrates (Schimel and Weintraub 2003).

\section{Interspecific differences in decay rates}

The decay pattern of leaf litter of all species followed a single exponential function, only differing in the mass remaining over time. The kinetics of decay (decay constants, leaf half-life and 95\% lifespan) observed in this study are comparable to findings by Ashton et al. (1999), Chanda et al. (2016), and Kamal et al. (2020) (Table 3). Leaf litter was observed to disintegrate physically and fragment within 14 days for Acanthus, within 35 days for Rhizophora and Bruguiera, and within 70 days for Acrostichum. Similar to a previous study by Ashton et al. (1999), litter of Rhizophora decayed faster than that of Bruguiera. Along the same line, significant interspecific differences were observed in litter chemistry and enzyme activities, as well as in their respective patterns of change over time. Accordingly, pair-wise correlations of these litter characteristics with decay kinetics (litter half-life) suggested those parameters that drive decay rates in general (Fig. 4), as well as interspecific differences in decay rates (Fig. 5). It is mostly for the decay of Rhizophora litter that the parameters we measured correlate with litter half-life. 
Table 3 Comparison of decay constants $(\mathrm{k})$, goodness of fit $\left(R^{2}\right)$, leaf half-life and $95 \%$ lifespan of this study and other studies performed in Asian mangroves. IM and $\mathrm{M}$ differentiate immature and mature plants

\begin{tabular}{|c|c|c|c|c|c|c|}
\hline Mangrove species & Location & $\begin{array}{l}\text { Decay constant, } \\
\left(\text { day }^{-1}\right)\end{array}$ & $R^{2}$ & $t_{0.50}$ (days) & $t_{0.95}$ (days) & References \\
\hline \multirow{4}{*}{$\begin{array}{l}\text { Rhizophora api- } \\
\text { culata }\end{array}$} & Matang, Malaysia & $0.0091-0.0163$ & $0.635-0.884$ & $43-76$ & - & Ashton et al. (1999) \\
\hline & $\begin{array}{l}\text { Sundarbans, Bang- } \\
\text { ladesh }\end{array}$ & $0.13-0.14$ & $0.587-0.675$ & $35-37$ & - & Chanda et al. (2016) \\
\hline & Sibuti, Malaysia & $0.013-0.0103$ & $0.728-0.981$ & $55-68$ & $238-291$ & (Kamal et al. 2020) \\
\hline & Matang, Malaysia & $\begin{array}{l}0.0184(\mathrm{IM}) \\
0.0134(\mathrm{M})\end{array}$ & $\begin{array}{l}0.950(\mathrm{IM}) \\
0.918(\mathrm{M})\end{array}$ & 38 (IM) 52 (M) & 163 (IM) 224 (M) & This study \\
\hline \multirow{2}{*}{$\begin{array}{l}\text { Bruguiera parvi- } \\
\text { flora }\end{array}$} & Matang, Malaysia & $0.0057-0.0099$ & $0.618-0.747$ & $70-122$ & - & Ashton et al. (1999) \\
\hline & Matang, Malaysia & $\begin{array}{l}0.0116 \\
(\mathrm{IM} \& \mathrm{M})\end{array}$ & $\begin{array}{l}0.839 \text { (IM) } 0.876 \\
\text { (M) }\end{array}$ & $60(\mathrm{IM} \& \mathrm{M})$ & $\begin{array}{l}258(\mathrm{IM})-259 \\
(\mathrm{M})\end{array}$ & This study \\
\hline $\begin{array}{l}\text { Bruguiera gym- } \\
\quad \text { norhiza }\end{array}$ & $\begin{array}{l}\text { Okinawa, } \\
\text { Japan }\end{array}$ & 0.022 & 0.993 & 32 & - & $\begin{array}{l}\text { Mfilinge et al. } \\
\text { (2002) }\end{array}$ \\
\hline Nypa fructicans & $\begin{array}{l}\text { Sundarbans, Bang- } \\
\text { ladesh }\end{array}$ & $0.08-0.10$ & $0.489-0.730$ & $23-61$ & - & Chanda et al. (2016) \\
\hline $\begin{array}{l}\text { Acrostichum } \\
\text { aureum }\end{array}$ & Matang, Malaysia & $\begin{array}{l}0.0081(\mathrm{IM}) \\
0.0074(\mathrm{M})\end{array}$ & $\begin{array}{l}0.956(\mathrm{IM}) \\
0.905(\mathrm{M})\end{array}$ & $\begin{array}{l}93(\mathrm{IM}) \\
86(\mathrm{M})\end{array}$ & $\begin{array}{l}403(\mathrm{IM}) \\
370(\mathrm{M})\end{array}$ & This study \\
\hline Acanthus volubilis & $\begin{array}{l}\text { Sundarbans, Bang- } \\
\text { ladesh }\end{array}$ & $0.21-0.29$ & $0.606-0.701$ & $17-23$ & - & Chanda et al. (2016) \\
\hline Acanthus ilicifolius & Matang, Malaysia & $\begin{array}{l}0.0333 \text { (IM) } 0.0445 \\
\text { (M) }\end{array}$ & $\begin{array}{l}0.991(\mathrm{IM}) \\
0.984(\mathrm{M})\end{array}$ & $\begin{array}{l}21(\mathrm{IM}) \\
16(\mathrm{M})\end{array}$ & $\begin{array}{l}90(\mathrm{IM}) \\
67(\mathrm{M})\end{array}$ & This study \\
\hline
\end{tabular}

Besides purely quantitative differences among species and between ontogenetic stages (see below), qualitative differences in the phenolic signature appear to remarkably contribute to the explanation of decay patterns. Some dominant phenolic compounds of Rhizophora litter (Peaks 20-22; Fig. S3.1-2) were not, or only in small amounts, detected in other species. The dominant Peak 22 in the litter of immature Rhizophora and its lack in the litter from mature Rhizophora may be attributed to a specific phenolic compound that is produced during the early growth stages of this species and drives differences in decay rates between immature and mature Rhizophora. It remains unclear, though, how the dominance of these two peaks may drive the faster decay of Rhizophora litter compared to that of Bruguiera and Acrostichum. Peaks 11 and 12 were specific to Bruguiera and may thus explain partly the differences between the latter and Rhizophora. The lack or low contents of Peaks 6 and 20-22 in Acanthus might partly explain the significantly higher decay rates of this herbaceous species. On the other hand, a higher diversity of phenolic compounds in Bruguiera and Acrostichum litter may contribute to the deceleration of microbial activity during the early phase of decay.

Overall, the very low content of phenolics in Acanthus did not exhibit any measurable protein-precipitation capacity, possibly explaining the lack of effect of phenolics in Acanthus on microbial decay rates. Additional speciesspecific parameters probably also drive differences in decay rates, but among those we quantified herein, only the ones related to phenolic compounds and enzyme activity proved significant, whereas traditional predictors of decay rates, such as $\mathrm{N}$ content or $\mathrm{C}: \mathrm{N}$ ratio, had only little explanatory power. Even though the $\mathrm{C}: \mathrm{N}$ ratio of litter from Bruguiera was higher than that of the litter from Acrostichum, the former decayed faster than the latter. Some N compounds, such as alkaloids, are deterrent or even toxic for microorganisms. Acrostichum aureum was tested positive for alkaloids (Basyuni et al. 2019), and it contains abundant sterols, flavonoids, fatty acids and long-chain hydrocarbons (e.g. sesquiterpenes) (Uddin et al. 2011) that might be responsible for the slow decay of this species in our study.

\section{Ontogenetic differences in decay rates}

From the set of parameters we measured herein, total phenolic content, protein precipitation capacity, and phenol oxidase and cellulase activity significantly explained the variance in litter half-life for litter from mature plants (Fig. 6), which followed the correlation matrix of the entire data set (Fig. 4). For the litter from immature plants, we observed significant correlations between litter half-life and $\mathrm{N}$ content, phenol oxidase and cellulase activity. In general, the half-life of immature leaves was significantly decreased when initial $\mathrm{N}$ content and initial activities of phenol oxidases and cellulases were high. 

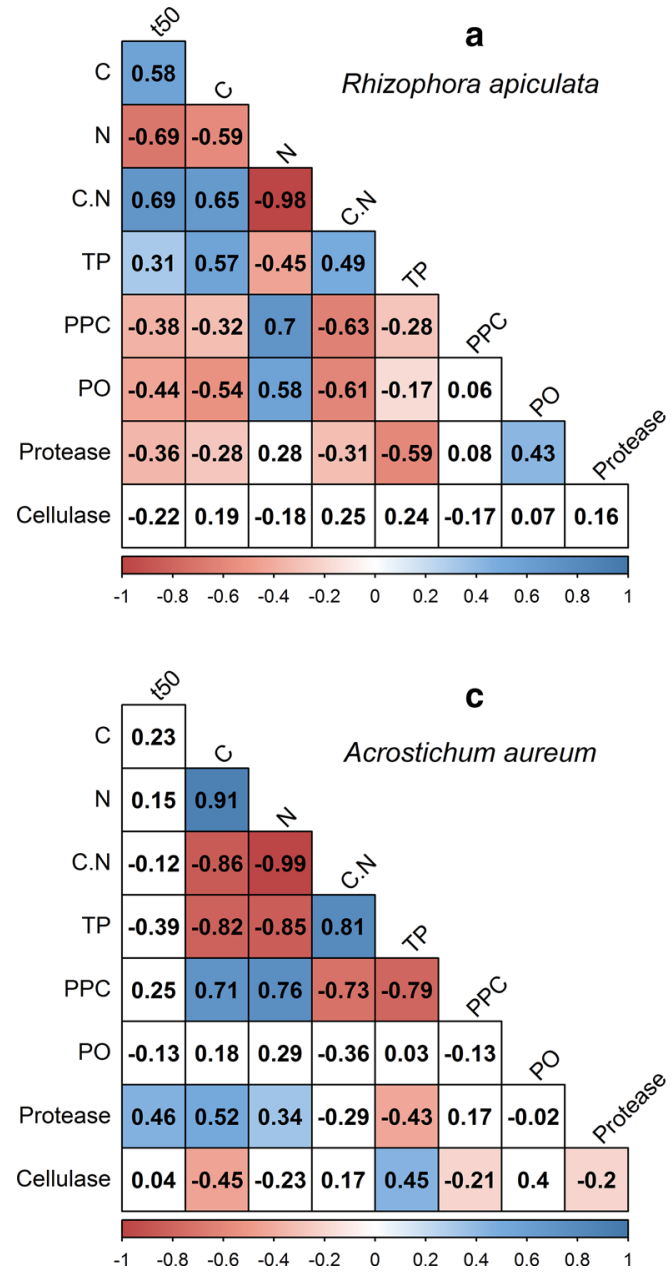

Fig. 5 Heat maps of correlation coefficients between leaf half-life $\left(t_{0.50}\right)$ of a Rhizophora apiculata, b Bruguiera parviflora, c Acrostichum aureum, $\mathbf{d}$ Acanthus ilicifolius, and initial litter characteristics

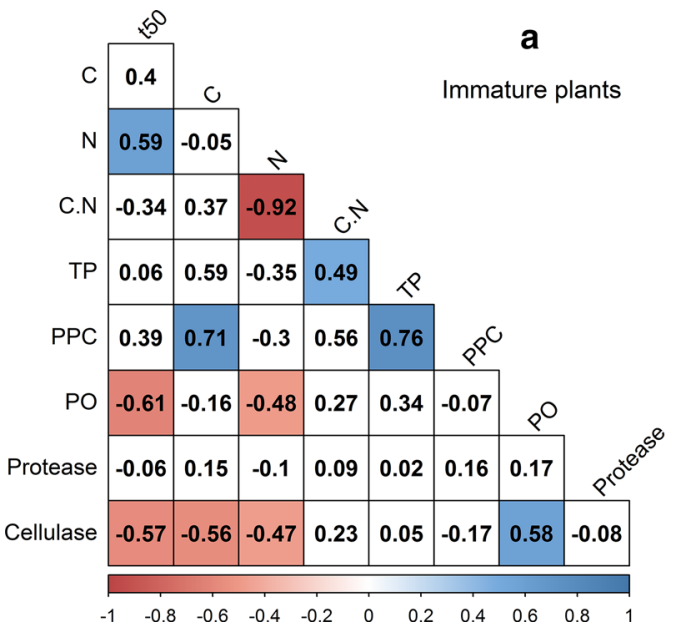

Fig. 6 Heat maps of correlation coefficients between leaf half-life $\left(t_{50}\right)$ of $\mathbf{a}$ immature plants and $\mathbf{b}$ mature plants, and initial litter characteristics at $\alpha=0.05$ ( $n$ for each maturity stages $=28$ ). $C$ carbon,
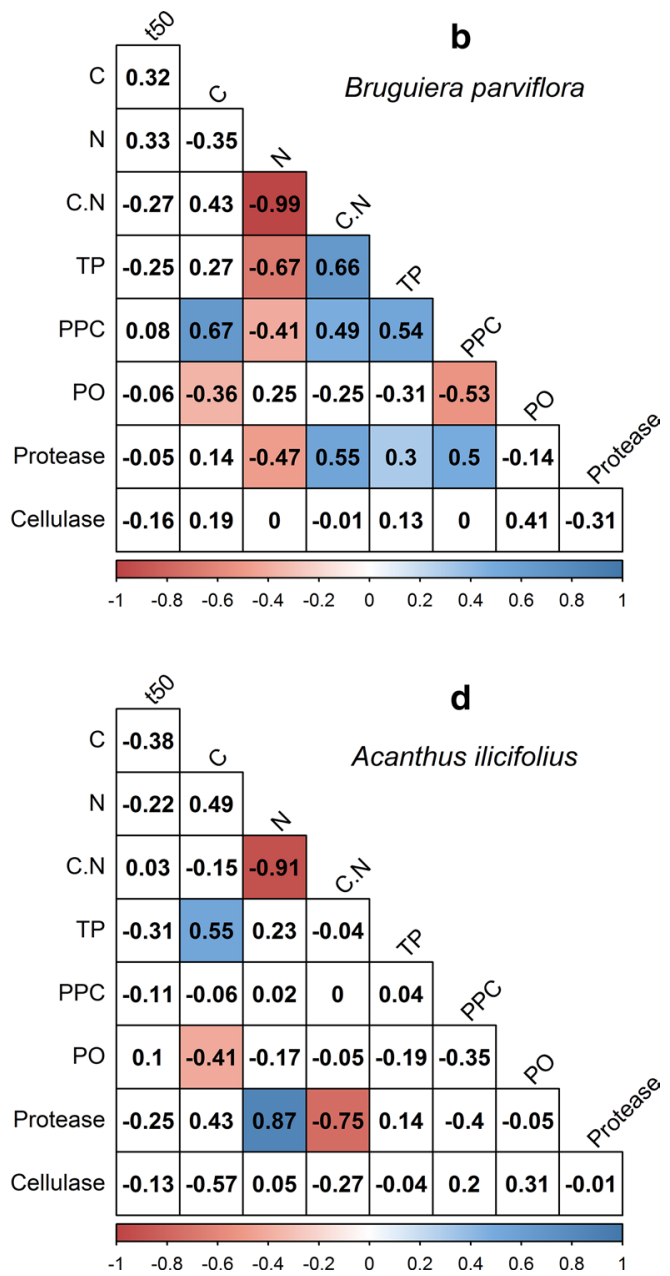

at $\alpha=0.05$ ( $n$ for each species $=14)$. $C$ carbon, $N$ nitrogen, $C . N C$-to$\mathrm{N}$ ratio, $T P$ total phenolics, $P P C$ protein precipitation capacity, $\mathrm{PO}=$ phenol oxidase

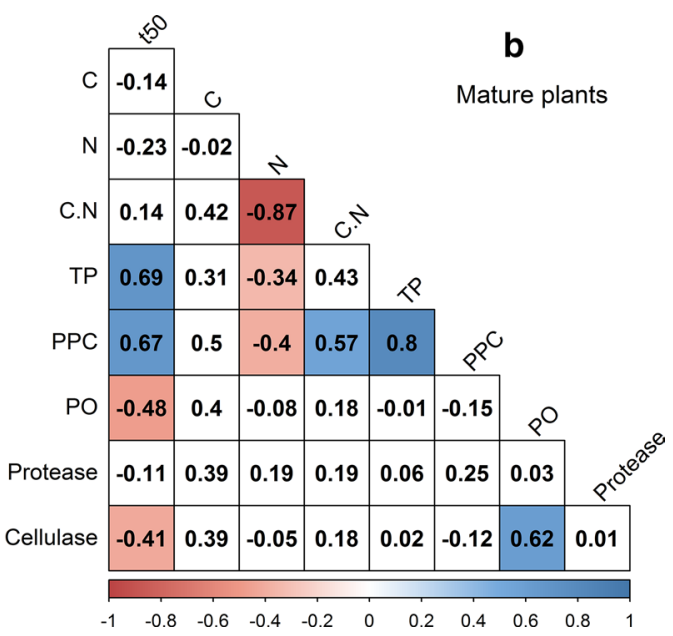

$N$ nitrogen, $C: N$ C-to-N ratio, $T P$ total phenolics, $P P C$ protein precipitation capacity, $P O$ phenol oxidase 
Our observations indicate that ontogenetic differences in the content and protein-precipitation capacity of phenolic compounds affect the variance in decay rates, as these quantitative measures of the phenolic signature were significantly different in mature plants but not in immature plants. Structural characteristics of foliar phenolics, especially tannins, can vary significantly among closely related species or even varieties and also may vary by physiological stage, season, and environmental conditions (Kraus et al. 2003b; Lin et al. 2006; Zimmer et al. 2015). The qualitative analysis of the phenolic fingerprints of different litter types yielded a clear pattern in that litter from immature Rhizophora had a clearly distinct phenolic fingerprint from the litter of all mature plants (Fig. 7). Litter from mature Rhizophora, by contrast, exhibited high similarity to the litter from both immature and mature Bruguiera and Acrostichum. Corresponding with the generally low phenolic content and the lack of protein-precipitation capacity of Acanthus litter, this species was clearly separated from the other species regarding the phenolic fingerprint. Compared to other species, the dissimilarity of phenolic signatures of litter from immature Rhizophora was clearly shown in Peak 22 (49\% of total peak area) that was lacking from a litter from mature Rhizophora and had very low contents ( $<2 \%$ of total peak area) in other species (Table S3.1). On the other hand, the phenolic fingerprint of litter from mature Rhizophora was different from that of litter from immature plants and other species in Peak 20 (17\%).

Despite the clear differences in litter chemistry between ontogenetic stages of the same species, we detected only weak effects of the ontogenetic stage on decay rates. However, the within-species comparison demonstrated that litter from mature Rhizophora had a by about $40 \%$ increased lifetime $(99 \%)$ compared to litter from immature plants of the same species. Faster decay of litter from immature Rhizophora can be interpreted as (1) faster release of $\mathrm{CO}_{2}$ upon microbial decay, but at the same time (2) increased release of organic matter into the sediment and porewater where it will be microbially immobilized and transformed into recalcitrant humic substances and stored under anoxic conditions for decades and centuries (Kida et al. 2019). While silivicultural mangrove stands lose parts of their C- and N-stocks upon clear-felling (Adame et al. 2018), we hold that the actual sequestration rate of $\mathrm{C}$ into the sediment might be higher upon reforestation of clear-cut areas underneath immature fast-growing Rhizophora trees than under mature trees with low relative growth rates. Further studies are needed to confirm this hypothesis.

\section{Implications for mangrove forest management}

According to the findings of the present study, changes in species composition of mangroves over time, such as observed over the successional stage after disturbance, will result in changes in litter chemistry, and thus, decay rates (c.f. Quadros et al. 2019) which, in turn, will translate into changes in storage rates and eventually stores of organic matter in the sediment. The common assumption that high initial $\mathrm{N}$ content and low $\mathrm{C}: \mathrm{N}$ ratio influence the fast decay of mangrove leaf litter, however, is not corroborated by the findings of this study. Significant differences in the phenolic signature of leaves from immature vs mature Rhizophora, on the other hand, seem to drive the faster decay of litter from immature plants. It remains an open question as to whether

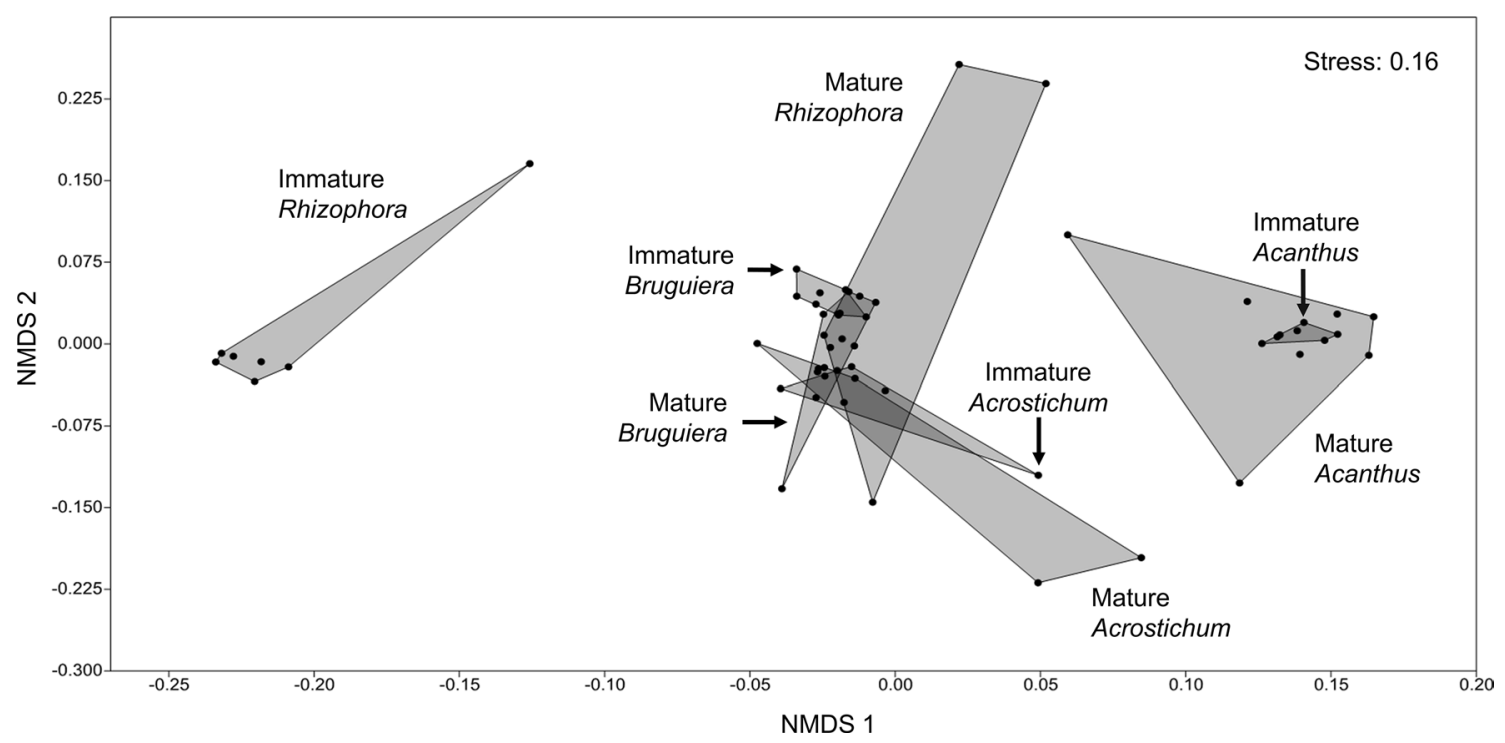

Fig. 7 Non-metric multidimensional scaling (NMDS) plot of phenolic signatures of individual plants with different species and maturity stages grouped into different convex hulls. IM and $\mathrm{M}$ differentiate immature and mature plants 
the differences in decay rates of litter from mature vs immature Rhizophora increase $\mathrm{CO}_{2}$ release into the atmosphere or foster the storage of organic matter in the sediment. The answer to this question will help us understand what spatially limited clearcutting of mangrove patches means for organic matter turnover dynamics and organic matter stocks in the sediment. Frequent rejuvenation of mangrove stands through controlled and spatially limited clearcutting and long-term use of logs for construction, rather than using them as firewood or processing them into charcoal, might prove an efficient tool for increasing the blue carbon-storage efficiency of mangrove stands.

Supplementary Information The online version contains supplementary material available at https://doi.org/10.1007/s00442-021-04865-3.

Acknowledgements The authors thank the Forestry Department of Peninsular Malaysia and the Perak Forestry Department for issuing the research permit and the staffs of the Matang Mangrove Forest Reserve for their assistance during fieldwork. We acknowledge Dr. Rozaimi Jamaluddin (FST UKM) for laboratory access in Malaysia and Christina Staschok (ZMT) for conducting HPLC analysis. The study was supported by UKM Research Grant (GUP-2018-120). NAP was funded by Development-Related Postgraduate Courses (EPOS) scholarship from the German Academic Exchange Academy (DAAD).

Author contribution statement NAP, AAA and MZ conceived the ideas and designed methodology; NAP collected and analyzed the data; NAP, AAA and MZ wrote the manuscript. All authors contributed critically to the manuscript and gave final approval for publication.

Funding Open Access funding enabled and organized by Projekt DEAL.

\section{Compliance with ethical standards}

Conflict of interest The authors declare that they have no conflict of interest.

Open Access This article is licensed under a Creative Commons Attribution 4.0 International License, which permits use, sharing, adaptation, distribution and reproduction in any medium or format, as long as you give appropriate credit to the original author(s) and the source, provide a link to the Creative Commons licence, and indicate if changes were made. The images or other third party material in this article are included in the article's Creative Commons licence, unless indicated otherwise in a credit line to the material. If material is not included in the article's Creative Commons licence and your intended use is not permitted by statutory regulation or exceeds the permitted use, you will need to obtain permission directly from the copyright holder. To view a copy of this licence, visit http://creativecommons.org/licenses/by/4.0/.

\section{References}

Adame MF, Zakaria RM, Fry B et al (2018) Loss and recovery of carbon and nitrogen after mangrove clearing. Ocean Coast Manag 161:117-126. https://doi.org/10.1016/j.ocecoaman.2018.04.019

Ainsworth EA, Gillespie KM (2007) Estimation of total phenolic content and other oxidation substrates in plant tissues using Folin-Ciocalteu reagent. Nat Protoc 2:875. https://doi. org/10.1038/nprot.2007.102

Allison SD, Gartner TB, Holland K, et al (2007) Soil enzymes: linking proteomics and ecological processes. In: Manual of Environmental Microbiology, Third Edition. American Society of Microbiology, pp 704-711

Alongi DM (2002) Present state and future of the world's mangrove forests. Environ Conserv 29:331-349. https://doi.org/10.1017/ S0376892902000231

Alongi DM, Dixon P (2000) Mangrove primary production and aboveand below-ground biomass in Sawi Bay, southern Thailand. Phuket Mar Biol Cent Spec Publ 22:31-38

Amir AA (2012) Canopy gaps and the natural regeneration of Matang mangroves. For Ecol Manage 269:60-67. https://doi. org/10.1016/j.foreco.2011.12.040

Ananda K, Sridhar KR, Raviraja NS, Bärlocher F (2008) Breakdown of fresh and dried Rhizophora mucronata leaves in a mangrove of Southwest India. Wetl Ecol Manag 16:1-9. https://doi. org/10.1007/s11273-007-9041-y

Anderson MJ (2001) A new method for non-parametric multivariate analysis of variance. Austral Ecol 26:32-46. https://doi.org/10.1 111/j.1442-9993.2001.01070.pp.x

Arfi Y, Buée M, Marchand C et al (2012) Multiple markers pyrosequencing reveals highly diverse and host-specific fungal communities on the mangrove trees Avicennia marina and Rhizophora stylosa. FEMS Microbiol Ecol 79:433-444. https://doi.org/10.11 11/j.1574-6941.2011.01236.x

Ariffin R, Nik Mohd Shah NM (2013) A working plan for the Matang Mangrove Forest Reserve, Perak: sixth revision of the first 10-year period (2010-2019) of the third rotation. State For Dep Perak, Perak, p 229

Ashton EC, Hogarth PJ, Ormond R (1999) Breakdown of mangrove leaf litter in a managed mangrove forest in Peninsular Malaysia. Hydrobiologia 413:77-88. https://doi.org/10.1023/A:1003842910 811

Bandaranayake WM (1995) Survey of mangrove plants from Northern Australia for phytochemical constituents and UV-absorbing compounds. Curr Top Phytochem (Life Sci Adv) 14:69-78

Bärlocher F, Graça MAS (2005) Total Phenolics. In: Graça MAS, Bärlocher F, Gessner MO (eds) Methods to study litter decomposition: a practical guide. Springer, Dordrecht, pp 97-100

Basyuni M, Sari D, Illian DN et al (2019) Phytochemical, physicochemical, and microscopic analysis of five true mangrove leaves. In: AIP conference proceedings. $\mathrm{p} 30006$

Berger U, Hildenbrandt H, Grimm V (2004) Age-related decline in forest production: modelling the effects of growth limitation, neighbourhood competition and self-thinning. J Ecol 92:846-853. https ://doi.org/10.1111/j.0022-0477.2004.00911.x

Bosire JO, Dahdouh-Guebas F, Kairo JG et al (2005) Litter degradation and $\mathrm{CN}$ dynamics in reforested mangrove plantations at Gazi Bay, Kenya. Biol Conserv 126:287-295. https://doi.org/10.1016/j. biocon.2005.06.007

Bouillon S, Moens T, Koedam N et al (2004) Variability in the origin of carbon substrates for bacterial communities in mangrove sediments. FEMS Microbiol Ecol 49:171-179. https://doi. org/10.1016/j.femsec.2004.03.004

Cahoon DR, Hensel P, Rybczyk J et al (2003) Mass tree mortality leads to mangrove peat collapse at Bay Islands, Honduras after Hurricane Mitch. J Ecol 91:1093-1105. https://doi.org/10.104 6/j.1365-2745.2003.00841.x

Chanda A, Akhand A, Manna S et al (2016) Mangrove associates versus true mangroves: a comparative analysis of leaf litter decomposition in Sundarban. Wetl Ecol Manag 24:293-315. https://doi. org/10.1007/s11273-015-9456-9 
Charney J, Tomarelli RM (1947) A colorimetric method for the determination of the proteolytic activity of duodenal juice. J Biol Chem 171:501-505. https://doi.org/10.1038/ngeo1123

Clarke KR (1993) Non-parametric multivariate analyses of changes in community structure. Aust J Ecol 18:117-143. https://doi. org/10.1111/j.1442-9993.1993.tb00438.x

Clough BF, Tan DT, Buu DC, Phuong DX (1999) Mangrove forest structure and growth. In: Clough B (ed) Mixed Shrimp FarmingMangrove Forestry Models in the Mekong Delta, Termination Report, Part B: Technical Appendices. Australian Centre for International Agricultural Research, Canberra, ACT, Australia, pp 235-251

Constabel CP, Yoshida K, Walker V (2014) Diverse ecological roles of plant tannins: plant defense and beyond. In: Recent Advances in Polyphenol Research. Wiley-Blackwell, pp 115-142

Cornwell W, Cornelissen J, Amatangelo K et al (2008) Plant species traits are the predominant control on litter decomposition rates within biomes worldwide. Ecol Lett 11:1065-1071. https://doi. org/10.1111/j.1461-0248.2008.01219.x

Cotrufo MF, Wallenstein MD, Boot CM et al (2013) The Microbial Efficiency-Matrix Stabilization (MEMS) framework integrates plant litter decomposition with soil organic matter stabilization: do labile plant inputs form stable soil organic matter? Glob Chang Biol 19:988-995. https://doi.org/10.1111/gcb.12113

Das M, Royer TV, Leff LG (2007) Diversity of fungi, bacteria, and actinomycetes on leaves decomposing in a stream. Appl Environ Microbiol 73:756-767. https://doi.org/10.1128/AEM.01170-06

de Menezes YAS, Félix-Silva J, da Silva-Júnior AA et al (2014) Protein-rich fraction of Cnidoscolus urens (L.) Arthur leaves: enzymatic characterization and procoagulant and fibrinogenolytic activities. Molecules 19:3552-3569. https://doi.org/10.3390/ molecules19033552

Donato DC, Kauffman JB, Murdiyarso D et al (2011) Mangroves among the most carbon-rich forests in the tropics. Nat Geosci 4:293. https://doi.org/10.1038/ngeo1123

Duke NC (2001) Gap creation and regenerative processes driving diversity and structure of mangrove ecosystems. Wetl Ecol Manag 9:267-279. https://doi.org/10.1023/A:1011121109886

Duke NC (2011) Mangroves. In: Encyclopedia of modern coral reefs. structure, form and process. Springer, pp 655-663

Feller IC, Lovelock CE, Berger U et al (2010) Biocomplexity in mangrove ecosystems. Ann Rev Mar Sci 2:395-417. https://doi. org/10.1146/annurev.marine.010908.163809

Freschet GT, Aerts R, Cornelissen JHC (2012) A plant economics spectrum of litter decomposability. Funct Ecol 26:56-65. https://doi. org/10.1111/j.1365-2435.2011.01913.x

Gleixner G (2013) Soil organic matter dynamics: a biological perspective derived from the use of compound-specific isotopes studies. Ecol Res 28:683-695. https://doi.org/10.1007/s11284-012-1022-9

Goessens A, Satyanarayana B, Van der Stocken T et al (2014) Is Matang Mangrove Forest in Malaysia sustainably rejuvenating after more than a century of conservation and harvesting management? PLoS ONE 9:e105069. https://doi.org/10.1371/journ al.pone. 0105069

Gower ST, McMurtrie RE, Murty D (1996) Aboveground net primary production decline with stand age: potential causes. Trends Ecol Evol 11:378-382. https://doi.org/10.1016/0169-5347(96)10042-2

Graça MAS, Bärlocher F (2005) Radial diffusion assay for tannins. In: Graça MAS, Bärlocher F, Gessner MO (eds) Methods to study litter decomposition: a practical guide. Springer, Dordrecht, pp $101-105$

Hagerman AE (1987) Radial diffusion method for determining tannin in plant extracts. J Chem Ecol 13:437-449. https://doi. org/10.1007/BF01880091

Hamdan O, Khali Aziz H, Mohd Hasmadi I (2014) L-band ALOS PALSAR for biomass estimation of Matang Mangroves, Malaysia.
Remote Sens Environ 155:69-78. https://doi.org/10.1016/j. rse.2014.04.029

Hammer Ø, Harper DAT, Ryan PD (2001) PAST: Paleontological statistics software package for education and data analysis. Palaeontol Electron 4:1-9

Hardoim PR, van Overbeek LS, Berg G et al (2015) The hidden world within plants: ecological and evolutionary considerations for defining functioning of microbial endophytes. Microbiol Mol Biol Rev 79:293-320. https://doi.org/10.1128/MMBR.00050-14

Hernes PJ, Benner R, Cowie GL et al (2001) Tannin diagenesis in mangrove leaves from a tropical estuary: a novel molecular approach. Geochim Cosmochim Acta 65:3109-3122. https://doi. org/10.1016/S0016-7037(01)00641-X

Iftekhar S, Islam RM (2004) Managing mangroves in Bangladesh: a strategy analysis. J Coast Conserv 10:139-146. https://doi. org/10.1007/BF02818950

Jimenez JA, Lugo AE, Cintron G (1985) Tree mortality in mangrove forests. Biotropica. https://doi.org/10.2307/2388214

Kamal AHM, Hoque MM, Idris MH et al (2020) Decay of Rhizophora apiculata (Blume) and Xylocarpus granatum (Koenig) detrital sources in the Sarawak Mangrove, Malaysia. J For Res 31:613623. https://doi.org/10.1007/s11676-018-0776-5

Kida M, Kondo M, Tomotsune M et al (2019) Molecular composition and decomposition stages of organic matter in a mangrove mineral soil with time. Estuar Coast Shelf Sci 231:106478. https://doi. org/10.1016/j.ecss.2019.106478

Komiyama A, Ong JE, Poungparn S (2008) Allometry, biomass, and productivity of mangrove forests: a review. Aquat Bot 89:128137. https://doi.org/10.1016/j.aquabot.2007.12.006

Kraus TEC, Dahlgren RA, Zasoski RJ (2003a) Tannins in nutrient dynamics of forest ecosystems-a review. Plant Soil 256:41-66. https://doi.org/10.1023/A:1026206511084

Kraus TEC, Yu Z, Preston CM et al (2003b) Linking chemical reactivity and protein precipitation to structural characteristics of foliar tannins. J Chem Ecol 29:703-730. https://doi. org/10.1023/A:1022876804925

Krishna MP, Mohan M (2017) Litter decomposition in forest ecosystems: a review. Energy Ecol Environ 2:236-249. https://doi. org/10.1007/s40974-017-0064-9

Li T, Ye Y (2014) Dynamics of decomposition and nutrient release of leaf litter in Kandelia obovata mangrove forests with different ages in Jiulongjiang Estuary, China. Ecol Eng 73:454-460. https ://doi.org/10.1016/j.ecoleng.2014.09.102

Liang C, Schimel JP, Jastrow JD (2017) The importance of anabolism in microbial control over soil carbon storage. Nat Microbiol 2:17105. https://doi.org/10.1038/nmicrobiol.2017.105

Lin YM, Liu JW, Xiang P et al (2006) Tannin dynamics of propagules and leaves of Kandelia candel and Bruguiera gymnorrhiza in the Jiulong River Estuary, Fujian, China. Biogeochemistry 78:343359. https://doi.org/10.1007/s10533-005-4427-5

Linkins AE, Sinsabaugh RL, McClaugherty CA, Melills JM (1990) Cellulase activity on decomposing leaf litter in microcosms. Plant Soil 123:17-25. https://doi.org/10.1007/BF00009922

Magurran AE (2004) Measuring biological diversity. Blackwell Publishing, Oxford

Maie N, Pisani O, JaffÉ R (2008) Mangrove tannins in aquatic ecosystems: their fate and possible influence on dissolved organic carbon and nitrogen cycling. Limnol Oceanogr 53:160-171. https://doi. org/10.4319/lo.2008.53.1.0160

Manzoni S, Jackson RB, Trofymow JA, Porporato A (2008) The global stoichiometry of litter nitrogen mineralization. Science 321:684 686. https://doi.org/10.1126/science.1159792

Mfilinge P, Atta N, Tsuchiya M (2002) Nutrient dynamics and leaf litter decomposition in a subtropical mangrove forest at Oura Bay, Okinawa, Japan. Trees 16:172-180. https://doi.org/10.1007/s0046 8-001-0156-0 
Mfilinge PL, Meziane T, Bachok Z (2003) Fatty acids in decomposing mangrove leaves: microbial activity, decay and nutritional quality. Mar Ecol Prog Ser 265:97-105. https://doi.org/10.3354/meps2 65097

Mfilinge PL, Meziane T, Bachok Z, Tsuchiya M (2005) Litter dynamics and particulate organic matter outwelling from a subtropical mangrove in Okinawa Island, South Japan. Estuar Coast Shelf Sci 63:301-313. https://doi.org/10.1016/j.ecss.2004.11.022

Muda A, Mustafa N (2003) A working plan for the Matang Mangrove Forest Reserve, Perak (Fifth revision)

Murdiyarso D, Purbopuspito J, Kauffman JB et al (2015) The potential of Indonesian mangrove forests for global climate change mitigation. Nat Clim Chang 5:1089-1092. https://doi.org/10.1038/nclim ate 2734

Nga BT, Tinh HQ, Tam DT et al (2005) Young mangrove stands produce a large and high quality litter input to aquatic systems. Wetl Ecol Manag 13:569-576. https://doi.org/10.1007/s11273-004-6073-4

Ong JE, Wooi Khoon G, Clough BF (1995) Structure and productivity of a 20-year-old stand of Rhizophora apiculata Bl. mangrove forest. J Biogeogr 417-424

Opsahl S, Benner R (1995) Early diagenesis of vascular plant tissues: Lignin and cutin decomposition and biogeochemical implications. Geochim Cosmochim Acta 59:4889-4904. https://doi. org/10.1016/0016-7037(95)00348-7

Otero V, Van De Kerchove R, Satyanarayana B et al (2019) An analysis of the early regeneration of mangrove forests using Landsat time series in the Matang Mangrove Forest Reserve, Peninsular Malaysia. Remote Sens 11:774. https://doi.org/10.3390/rs11070774

Perucci P, Casucci C, Dumontet S (2000) An improved method to evaluate the o-diphenol oxidase activity of soil. Soil Biol Biochem 32:1927-1933. https://doi.org/10.1016/S0038-0717(00)00168-1

Prescott CE (2005) Do rates of litter decomposition tell us anything we really need to know? For Ecol Manage 220:66-74. https://doi. org/10.1016/j.foreco.2005.08.005

Priya G, Lau N-S, Furusawa G et al (2018) Metagenomic insights into the phylogenetic and functional profiles of soil microbiome from a managed mangrove in Malaysia. Agric Gene 9:5-15. https://doi. org/10.1016/j.aggene.2018.07.001

Quadros AF, Nordhaus I, Reuter H, Zimmer M (2019) Modelling of mangrove annual leaf litterfall with emphasis on the role of vegetation structure. Estuar Coast Shelf Sci 218:292-299. https://doi. org/10.1016/j.ecss.2018.12.012

R Core Team (2018) R: A language and environment for statistical computing. R Foundation for Statistical Computing

Ryan MG, Binkley D, Fownes JH (1997) Age-related decline in forest productivity: pattern and process. In: Begon M, Fitter AH (eds) Advances in ecological research. Academic Press, pp 213-262

Saiya-Cork KR, Sinsabaugh RL, Zak DR (2002) The effects of long term nitrogen deposition on extracellular enzyme activity in an Acer saccharum forest soil. Soil Biol Biochem 34:1309-1315. https://doi.org/10.1016/S0038-0717(02)00074-3

Schimel JP, Bennett J (2004) Nitrogen mineralization: challenges of a changing paradigm. Ecology 85:591-602. https://doi. org/10.1890/03-8002

Schimel JP, Weintraub MN (2003) The implications of exoenzyme activity on microbial carbon and nitrogen limitation in soil: a theoretical model. Soil Biol Biochem 35:549-563. https://doi. org/10.1016/S0038-0717(03)00015-4

Schultz J, Appel H, Ferrieri A, Arnold T (2013) Flexible resource allocation during plant defense responses. Front Plant Sci 4:324. https://doi.org/10.3389/fpls.2013.00324
Sharpe JM, Mehltreter K (2010) Ecological insights from fern population dynamics. In: Sharpe JM, Mehltreter K, Walker LR (eds) Fern Ecology. Cambridge University Press, Cambridge, pp 61-110

Sillanpää M, Vantellingen J, Friess DA (2017) Vegetation regeneration in a sustainably harvested mangrove forest in West Papua, Indonesia. For Ecol Manage 390:137-146. https://doi.org/10.1016/j. foreco.2017.01.022

Sinsabaugh RL, Lauber CL, Weintraub MN et al (2008) Stoichiometry of soil enzyme activity at global scale. Ecol Lett 11:1252-1264. https://doi.org/10.1111/j.1461-0248.2008.01245.x

Skambracks D, Zimmer M (1998) Combined methods for the determination of microbial activity of leaf litter. Eur J Soil Biol 34:105110. https://doi.org/10.1016/S1164-5563(00)88646-X

Tam NF, Vrijmoed LLP, Wong YS (1990) Nutrient dynamics associated with leaf decomposition in a small subtropical mangrove community in Hong Kong. Bull Mar Sci 47:68-78

Tremblay L, Benner R (2006) Microbial contributions to N-immobilization and organic matter preservation in decaying plant detritus. Geochim Cosmochim Acta 70:133-146. https://doi.org/10.1016/j. gca.2005.08.024

Uddin SJ, Jason TLH, Beattie KD et al (2011) (2S,3S)-Sulfated pterosin $\mathrm{C}$, a cytotoxic sesquiterpene from the Bangladeshi mangrove fern Acrostichum aureum. J Nat Prod 74:2010-2013. https://doi. org/10.1021/np2004598

Valiela I, Teal JM, Allen SD et al (1985) Decomposition in salt marsh ecosystems: the phases and major factors affecting disappearance of above-ground organic matter. J Exp Mar Bio Ecol 89:29-54. https://doi.org/10.1016/0022-0981(85)90080-2

van Oudenhoven A, Siahainenia JA, Sualia I et al (2015) Effects of different management regimes on mangrove ecosystem services in Java, Indonesia. Ocean Coast Manag 116:353-367. https://doi. org/10.1016/j.ocecoaman.2015.08.003

Wafar S, Untawale AG, Wafar M (1997) Litter fall and energy flux in a mangrove ecosystem. Estuar Coast Shelf Sci 44:111-124. https ://doi.org/10.1006/ecss.1996.0152

Wittstock U, Gershenzon J (2002) Constitutive plant toxins and their role in defense against herbivores and pathogens. Curr Opin Plant Biol 5:300-307. https://doi.org/10.1016/S1369-5266(02)00264-9

Zhang K, Simard M, Ross M et al (2008) Airborne laser scanning quantification of disturbances from hurricanes and lightning strikes to mangrove forests in Everglades National Park, USA. Sensors 8:2262-2292. https://doi.org/10.3390/s8042262

Zhou H-C, Tam NF, Lin Y-M et al (2012) Changes of condensed tannins during decomposition of leaves of Kandelia obovata in a subtropical mangrove swamp in China. Soil Biol Biochem 44:113-121. https://doi.org/10.1016/j.soilbio.2011.09.015

Zimmer M (2005a) Phenol Oxidation. In: Graça MAS, Bärlocher F, Gessner MO (eds) Methods to study litter decomposition: a practical guide. Springer, Dordrecht, pp 279-282

Zimmer M (2005b) Cellulases. In: Graça MAS, Bärlocher F, Gessner MO (eds) Methods to study litter decomposition: a practical guide. Springer, Dordrecht, pp 249-254

Zimmer M (2019) Detritus. Encyclopedia of ecology (Second Edition). Elsevier, Oxford, pp 292-301

Zimmer M, Auge H, von Wühlisch G et al (2015) Environment rather than genetic background explains intraspecific variation in the protein-precipitating capacity of phenolic compounds in beech litter. Plant Ecol Divers 8:73-79. https://doi.org/10.1080/17550 874.2013.871655 